\title{
Short communication: \\ Diversity of bird species in Air Telang Protected Forest, South Sumatra, Indonesia
}

\author{
SYAIFUL EDDY ${ }^{1}$, DIAN MUTIARA ${ }^{2}$, ROSWITHA YEMIMA TIUR MEDISWATI ${ }^{2}$, RAMA GIVATI RAHMAN ${ }^{2}$, \\ NORIL MILANTARA ${ }^{3}$, MOHAMMAD BASYUNI ${ }^{4,5, \boldsymbol{r}}$ \\ ${ }^{1}$ Department of Environmental Science, Faculty of Natural Sciences and Technology, Universitas PGRI Palembang. Jl. Jend. A. Yani, 9/10 Ulu, \\ Palembang 30251, South Sumatra, Indonesia \\ ${ }^{2}$ Department of Biology, Faculty of Natural Sciences and Technology, Universitas PGRI Palembang. Jl. Jend. A. Yani, 9/10 Ulu, Palembang 30251, \\ South Sumatra, Indonesia \\ ${ }^{3}$ Faculty of Forestry, Universitas Muhammadiyah Sumatera Barat. Jl. Pasir Kandang No. 4, Koto Tangah, Padang 25172, West Sumatra, Indonesia \\ ${ }^{4}$ Department of Forestry, Faculty of Forestry, Universitas Sumatera Utara. Jl. Tri Dharma Ujung No. 1, Medan 20155, North Sumatra, Indonesia. \\ ${ }^{5}$ Center of Excellence for Mangrove, Universitas Sumatera Utara. Jl. Dr. T. Mansur No. 9, Medan 20155, North Sumatra, Indonesia. \\ Tel./fax.: +62-61-8201920, `email: m.basyuni@usu.ac.id
}

Manuscript received: 16 September 2021. Revision accepted: 9 November 2021.

\begin{abstract}
Eddy S, Mutiara D, Mediswati RYT, Rahman RG, Milantara N, Basyuni M. 2021. Short communication: Diversity of bird species in Air Telang Protected Forest, South Sumatra, Indonesia. Biodiversitas 22: 5274-5279. Birds belong to the mangrove forest ecosystem, which is important biodiversity for life and must be maintained. This study aimed to examine the diversity of bird species in Air Telang Protected Forest (ATPF) which has experienced massive degradation. Birds' observation was carried out using the purposive sampling method by exploring predetermined areas with binoculars and cameras and through direct observation. Birds were identified by analyzing their morphology, sound, and color. The research data obtained a total of 38 bird species that consist of 13 orders and 22 families. In addition, the results of this study obtained nine species of migratory birds and two species with near threatened (NT) status based on the IUCN Red List Category. This study is the first bird species inventory and identification research conducted in ATPF.
\end{abstract}

Keywords: Air Telang Protected Forest, birds, mangrove

\section{INTRODUCTION}

Birds are one of the species of biodiversity that is unique and must be preserved. They are the most important part of the ecosystem, which forms part of biodiversity that is beneficial for life (Gaston et al. 2018; Mosbech et al. 2018; Maurice et al. 2020). Birds act as significant bioindicators of land-use change owing to their sensitivity to changes in the ecosystem (Hakim et al. 2020). In addition, they act as controlling pest predators, scavengers, and seed dispersers and help pollinate plants (Calimpong et al. 2015).

Indonesia has more than 1700 species of birds (Birdlife International 2021). Birds are scattered throughout the islands of Indonesia, including Sumatra, which is one of the main islands (Puspitaningtyas 2018). Air Telang Protected Forest (ATPF) of North Sumatra, Indonesia is one of the protected forests located on the east coast of Sumatra Island, which is dominated by mangrove vegetation. It has been declared as a protected forest under the letter of Ministry of Forestry Number 76/Kpts-II/2001 concerning the Designation of Forest and Water Areas in the Province of South Sumatra. This protected forest is located in South Sumatra Province with an area of approximately 12,660.87 ha, which is currently being degraded and converted into coconut and oil palm plantations, ponds, ports, agricultural fields, and settlements.
The area of primary forest in ATPF has decreased over time. The remaining primary forest was 6585.28 ha or about 52\% in 2017 (Eddy et al. 2017) and was only 2936.06 ha or about 23\% in 2020 (Eddy et al. 2021a; Eddy et al. 2021b). Besides, the invasion of Nypa fruticans, a particular tree-level plant in this area, indicates that this mangrove forest has been disturbed (Eddy et al. 2019; Eddy et al. 2020). Land-use changes that occur in ATPF due to anthropogenic impacts also affect the loss of animal habitat and hence bird biodiversity. This is in accordance with the opinion of Alves et al. (2013) that human activity is the main factor that can threaten bird populations in an ecosystem due to anthropogenic actions.

The disruption of forest vegetation structure and the land changes that occur in ATPF impact its habitat conditions and the food supply of its organisms, especially birds. The existence of a bird community is influenced by various factors, including housing, food availability, and human activities (Khan 2017). According to Dinanti et al. (2018), the condition of forest vegetation considerably affects the life of birds in it and the presence of deforestation can disrupt bird communities in an ecosystem.

The identification of bird species in a protected forest is important because it can provide information about the presence of bird species in that area. Besides, knowing about endemic and migratory birds' existence plays a 
significant role in ensuring their existence in the area. The present research aimed to study the diversity of bird species in ATPF. No research has been conducted on the diversity of bird species in ATPF before, and therefore, we are interested in doing this research. The results of this study can contribute to the acquirement of information about the diversity of bird species and the efforts that can be made to conserve them in view of avoiding their extinction.

\section{MATERIALS AND METHODS}

\section{Study area}

This research was conducted in the Air Telang Protected Forest (ATPF) area, which is one of the mangrove forest areas located in Banyuasin District, South Sumatra Province, Indonesia, which has an area of approximately $12,660.87$ ha (Figure 1). It is located at coordinates $(470818,9749378)$ to $(491273,9714793)$ using the UTM coordinate system (zone $48 \mathrm{~S}$ ). It has area boundaries, namely (i) in the north where it is bordered by the Bangka Strait and the Banyuasin River, (ii) in the east where it is bordered by the Muara Telang Sub-district and Banyuasin II Sub-district, (iii) in the south where it is bordered by the Muara Telang Sub-district, and (iv) in the west where it is bordered by the Banyuasin River.

Birds' observation was carried out at several sample points in the secondary forest, shrubs, and ponds at the research location (Figure 2). Each point where birds were found was marked with a location point using GPS with a coordinate system using UTM (zone $48 \mathrm{~S}$ ). The coordinates of the locations where the birds were found can be seen in Table 1 .

Table 1. Coordinates of the results of the field survey using the Geographical Positioning System (GPS) with the UTM coordinate system (zone $48 \mathrm{~S}$ )

\begin{tabular}{cc}
\hline UTM coordinate $(\mathbf{X}, \mathbf{Y})$ & Existing condition \\
\hline 482012,9738846 & Secondary forest \\
481728,9738594 & Secondary forest \\
484164,9743337 & Secondary forest \\
482177,9738775 & Shrub \\
482229,9738735 & Shrub \\
482668,9738275 & Shrub \\
482176,9738773 & Pond \\
482059,9738987 & Pond \\
\hline
\end{tabular}

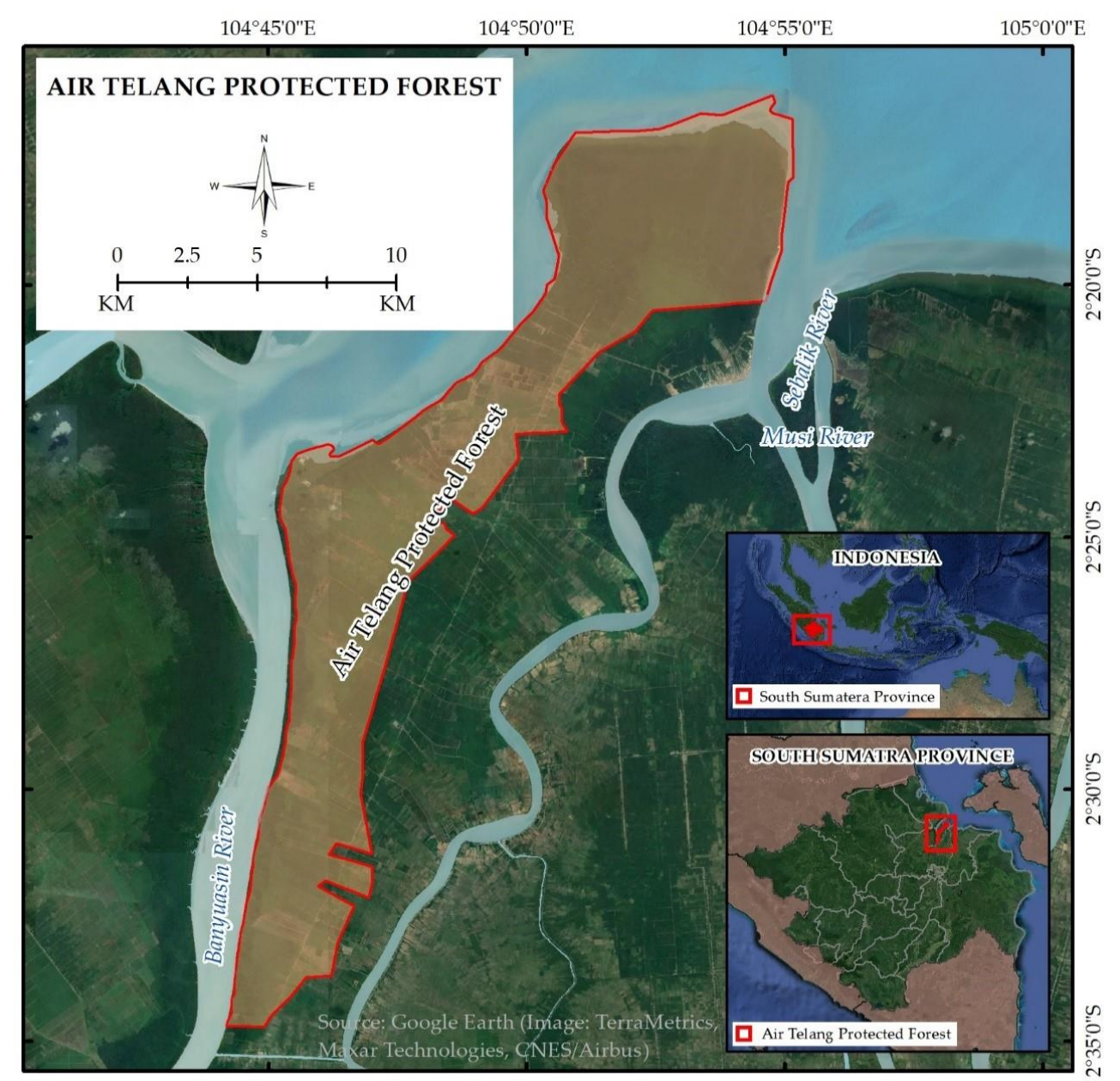

Figure 1. Map of research sites in the area of Telang Protected Forest (ATPF), Banyuasin District, South Sumatra Province, Indonesia 

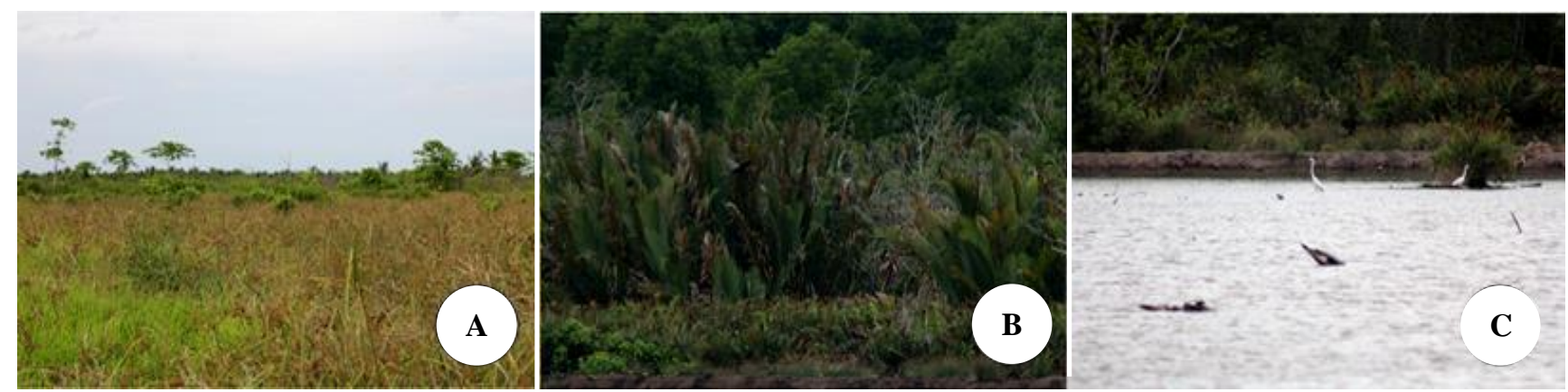

Figure 2. Research location in ATPF, South Sumatra, Indonesia, which includes shrubs (A), a secondary forest (B), and ponds (C)

\section{Bird sampling}

Birds' observation was carried out from April to May 2021. The method used was purposive sampling by exploring the ATPF area in the form of secondary forests, shrubs, and ponds where birds were estimated to be present. Observations at each station point were marked with a location point using GPS. Birds' observation was carried out twice a day; in the morning from 06.00 to 09.00 $\mathrm{AM}$ and in the afternoon from 03.00 to 6.00 PM (Yustian et al. 2017). The observation was repeated twice or thrice times for each observation location. The data obtained were recorded on a tally sheet, and pictures of the birds were taken using a camera or observed with binoculars in order to identify them. The birds found in the field were identified using the MacKinnon et al. (2010) guidebook.

\section{Data analysis}

Descriptive analysis is carried out by providing explanations in the form of descriptions based on data and information, namely visible facts. The data taken are secondary and primary data. Primary data includes environmental conditions, bird species, and interviews with the community, while secondary data was obtained using reference tracing to complete the primary data.

\section{RESULTS AND DISCUSSION}

A total of 38 bird species were obtained at ATPF, consisting of 13 orders and 22 families (Table 2). The order Passeriformes is the order with the highest number of species found, namely 15 species, while the dominant bird family is the Ardeidae family, which includes five species. The research results of Iswandaru et al. (2020) in degraded mangrove forests obtained 28 bird species that consist of 21 families. Most of the birds found were native to local habitats, and only nine species were migratory birds. There are two species with NT (Near Threatened) status based on the IUCN (International Union for Conservation of Nature) Red List Category, namely Oriental Darter (A. melanogaster) and Sunda Teal (A. gibberifrons). In addition, there were eight species found, which were water birds, namely Sunda Teal, Great White Egret, Little Egret, Cattle Egret, Javan Pond-Heron, Chinese Pond-Heron,
Great Cormorant, and Oriental Darter. Some of the bird species found in ATPF can be seen in Figure 3.

During the study, the bird species found in the field were seen doing activities like searching for food, flying, and perching on tree branches. The research location is dominated by wetlands such as swamps, ponds, and mangrove habitats. Mangrove plants in ATPF are dominated by Nypa fruticans, Rhizophora apiculata, and Acrostichum aureum (Eddy et al. 2019). The existence of wetland habitats, like swamps and ponds, supports the life of water birds as habitats and places for feeding. According to Asri et al. (2020), the most important factor affecting the presence of birds is a habitat that is of good quality thanks to the availability of sufficient food. Bird species richness in a particular place is significantly affected by the presence of trees that support the presence of birds (Labiran and Iwajomo 2018). Trees can provide for the needs of birds, being a place for them to make nests, lay eggs, and raise and provide food for young birds.

Familia Ardeidae is the family with the highest number of species found in ATPF. The species in this family are all found in ponds since they are waterbird species that use a lot of food in the water, such as fish and shrimp. According to Firdausy et al. (2021), Familia Ardeidae birds are water birds that live and nest in the waters and surrounding areas like mangrove forests. The Pycnonotidae family is the second dominant family after the Ardeidae family. Species of the Pycnonotidae family like to eat fruits and insects. Priyono et al. (2021) argue that birds of this species live in trees and eat fruits and insects. One species from the Pycnonotidae family, namely Sooty-Headed Bulbul $(P$. aurigaster), is often seen perching on trees or flying, which indicates that the ATPF environment still supports the existence of this species. The presence of birds in a habitat indicates that the habitat supports their life (Aryanti et al. 2018).

The birds found in the ATPF area are mostly carnivores that eat fish and insects, while the others are herbivores (eating nectar, leaves, fruits, and seeds). It is suspected that the high number of carnivorous waterbirds in the ATPF area is due to the areas dominated by wetlands, such as swamps, mangroves, and ponds, which have food supplies like fish crustaceans, mollusks, and insects which are favored by birds, especially water birds. According to Nagelkerken et al. (2008), the mangrove habitat is a 
supportive habitat owing to its abundance of bird food such as crustaceans, mollusks, and fish. The supporting factors for the presence of water birds are the availability of muddy habitats and the abundance of food sources from macrozoobenthos as the main food for waterbirds (Jumilawaty et al. 2011). Herbivorous birds like to be in trees and shrubs that produce fruits and flowers. They are often found in shrubs and secondary forests that have fruit and seed vegetation.

At the observation site, nine species of migratory birds were found, including Barn Swallow (H. rustica), Kentish Plover (Charadrius sp), Little Egret (E. garzetta), Great White Egret (A. alba), Cattle Egret (B. ibis), Chinese Pond-
Heron (A. bacchus), Osprey (Pandion haliaetus), Great Cormorant (Phalacrocorax carbo), and Eastern Spotted Dove (Spilopelia chinensis) (BirdLife International 2021). Migratory birds encountered are dominated by water birds who like to be in ponds adjacent to secondary forests. Habitats destruction on bird migration routes can disrupt the migration process. The success and continuity of bird migration depend on the habitats along the migration routes that serve as their temporary stopovers (Xu et al. 2019). According to Kolzsch and Blasius (2008), the movement process of migratory birds is not only influenced by time but also by individual differences, migration routes, climate change, and habitat destruction.

Table 2. Orders, families, and species of birds found in ATPF, South Sumatra Province, Indonesia during the study. The description for the column "location found" (P: Pond, S: Shrub, SF: Secondary forest) and "Status" is determined according to the Global IUCN (International Union for Conservation of Nature) Red List Category (LC: Least Concern, NT: Near Threatened)

\begin{tabular}{|c|c|c|c|c|c|c|}
\hline Order & Family & Species & English name & Local name & $\begin{array}{l}\text { Locatio } \\
\text { n found }\end{array}$ & Status \\
\hline \multirow[t]{2}{*}{ Accipitriformes } & Accipitridae & Elanus caeruleus & Black-Winged Kite & Elang Tikus & SF & $\mathrm{LC}$ \\
\hline & & Haliastur indus & Brahminy Kite & Elang Bondol & $\mathrm{P}, \mathrm{SF}$ & $\mathrm{LC}$ \\
\hline Apodiformes & Apodidae & Collocalia esculenta & Glossy Swiftlet & Walet & $\mathrm{P}, \mathrm{SF}$ & $\mathrm{LC}$ \\
\hline Caprimulgiformes & Caprimulgidae & Caprimulgus affinis & Savanna Nightjar & Cabak Kota & $\mathrm{S}$ & $\mathrm{LC}$ \\
\hline \multirow[t]{5}{*}{ Ciconiiformes } & Ardeidae & Ardea alba & Great White Egret & Kuntul Besar & $\mathrm{P}$ & $\mathrm{LC}$ \\
\hline & & Ardeola bacchus & Chinese Pond-Heron & Blekok Cina & $\mathrm{P}$ & $\mathrm{LC}$ \\
\hline & & Ardeola speciosa & Javan Pond-Heron & Blekok Sawah & $\mathrm{P}$ & $\mathrm{LC}$ \\
\hline & & Bubulcus ibis & Cattle Egret & Kuntul Kerbau & $\mathrm{P}$ & $\mathrm{LC}$ \\
\hline & & Egretta garzetta & Little Egret & Kuntul Kecil & $\mathrm{P}$ & $\mathrm{LC}$ \\
\hline Charadriiformes & Charadriidae & Charadrius sp & Kentish Plover & Cerek & $\mathrm{P}$ & $\mathrm{LC}$ \\
\hline \multirow[t]{3}{*}{ Columbiformes } & Columbidae & Geopelia striata & Zebra Dove & Perkutut & SF & $\mathrm{LC}$ \\
\hline & & Spilopelia chinensis & Eastern Spotted Dove & Tekukur & $\mathrm{S}, \mathrm{SF}$ & $\mathrm{LC}$ \\
\hline & & Treron vernans & $\begin{array}{l}\text { Pink-Necked Green- } \\
\text { Pigeon }\end{array}$ & Punai Gading & $\mathrm{S}, \mathrm{SF}$ & $\mathrm{LC}$ \\
\hline \multirow{2}{*}{ Coraciiformes } & & Halcyon smyrnensis & $\begin{array}{l}\text { White-Breasted } \\
\text { Kingfisher }\end{array}$ & Cekakak Belukar & $\mathrm{S}, \mathrm{SF}$ & $\mathrm{LC}$ \\
\hline & & Todiramphus chloris & Collared Kingfisher & Cekakak Sungai & $\mathrm{P}, \mathrm{SF}$ & $\mathrm{LC}$ \\
\hline Cuculiformes & Cuculidae & Centropus bengalensis & Lesser Coucal & Bubut Alang-Alang & $\mathrm{S}, \mathrm{SF}$ & $\mathrm{LC}$ \\
\hline Falconiformes & Pandionidae & Pandion haliaetus & Osprey & Elang Tiram & $\mathrm{P}$ & $\mathrm{LC}$ \\
\hline \multirow[t]{13}{*}{ Passeriformes } & Cisticolidae & Prinia flaviventris & Yellow-Bellied Prinia & Perenjak Rawa & $\mathrm{S}, \mathrm{SF}$ & $\mathrm{LC}$ \\
\hline & Corvidae & Corvus enca & Slender-Billed Crow & Gagak Hutan & $\mathrm{P}, \mathrm{SF}$ & $\mathrm{LC}$ \\
\hline & Estrildidae & Lonchura malacca & Tricoloured Munia & Bondol Rawa & $\mathrm{P}, \mathrm{S}, \mathrm{SF}$ & $\mathrm{LC}$ \\
\hline & Hirundinidae & Hirundo rustica & Barn Swallow & Sriti/Layang-Layang & $\mathrm{P}$ & $\mathrm{LC}$ \\
\hline & & Hirundo tahitica & Tahiti Swallow & Layang-Layang Batu & $\mathrm{P}, \mathrm{SF}$ & $\mathrm{LC}$ \\
\hline & Nectarinidae & Anthreptes simplex & Plain Sunbird & Madu/Madu Polos & SF & $\mathrm{LC}$ \\
\hline & & Aethopyga siparaja & Crimson Sunbird & Separaja/Madu Separaja & SF & $\mathrm{LC}$ \\
\hline & Passeridae & Passer montanus & Eurasian Tree Sparrow & Gereja & $\mathrm{P}, \mathrm{S}$ & $\mathrm{LC}$ \\
\hline & Pycnonotidae & Picnonotus aurigaster & Sooty-Headed Bulbul & Cucak Kutilang & $\mathrm{S}, \mathrm{SF}$ & $\mathrm{LC}$ \\
\hline & & Picnonotus goiavier & Yellow-Vented Bulbul & Merbah Cerukcuk & $\mathrm{S}, \mathrm{SF}$ & $\mathrm{LC}$ \\
\hline & & Picnonotus plumosus & Olive-Winged Bulbul & Merbah Belukar & $\mathrm{S}, \mathrm{SF}$ & $\mathrm{LC}$ \\
\hline & & Orthotomus ruficeps & Ashy Tailorbird & Cinenen Kelabu & $\mathrm{S}, \mathrm{SF}$ & $\mathrm{LC}$ \\
\hline & Zosteropidae & Zosterops palpebrosus & Indian White-Eye & Pleci & SF & $\mathrm{LC}$ \\
\hline \multirow[t]{2}{*}{ Piciformes } & Picidae & Chrysocolaptes validus & $\begin{array}{l}\text { Orange-Backed } \\
\text { Woodpecker }\end{array}$ & Pelatuk Kundang & SF & $\mathrm{LC}$ \\
\hline & & Dryocopus javanis & $\begin{array}{l}\text { White-Bellied } \\
\text { Woodpecker }\end{array}$ & Pelatuk Ayam & SF & $\mathrm{LC}$ \\
\hline \multirow[t]{2}{*}{ Suliformes } & Anhingidae & Anhinga melanogaster & Oriental Darter & Pecuk Ular & $\mathrm{P}, \mathrm{SF}$ & NT \\
\hline & Phalacrocoracidae & Phalacrocorax carbo & Great Cormorant & Pecuk & SF & $\mathrm{LC}$ \\
\hline
\end{tabular}



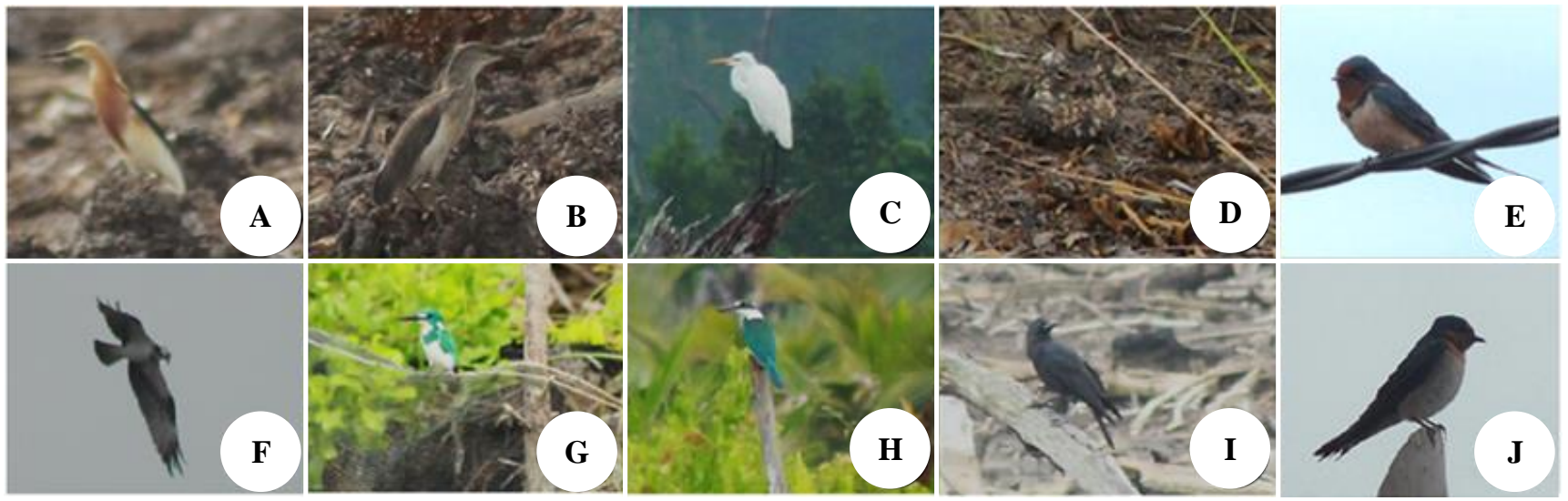

Figure 3. Several bird species found in the ATPF area, South Sumatra, Indonesia. A. Javan Pond-Heron (Ardeola speciosa), B. Chinese Pond-Heron (Ardeola bacchus), C. Cattle Egret (Bubulcus ibis), D. Savanna Nightjar (Caprimulgus affinis), E. Barn Swallow (Hirundo rustica), F. Osprey (Pandion haliaetus), G. Cerulean Kingfisher (Alcedo coerulescens), H. Collared Kingfisher (Todiramphus chloris), I. Slender-Billed Crow (Corvus enca) and J. Tahiti Swallow (Hirundo tahitica)

Table 3. The roles of bird species in the ecosystem found in ATPF, South Sumatra Province, Indonesia based on field observations and interviews with the community

\begin{tabular}{ll}
\hline \multicolumn{1}{c}{ Species } & \multicolumn{1}{c}{ Roles in the ecosystem } \\
\hline Aethopyga siparaja & Pollinate flowers \\
Alcedo coerulescens & Insect predators \\
Anas gibberifrons & Not identified \\
Anhinga melanogaster & Predators of fish and shrimp \\
Anthreptes simplex & Pollinate flowers \\
Ardea alba & Not identified \\
Ardeola bacchus & Not identified \\
Ardeola speciosa & Not identified \\
Bubulcus ibis & Not identified \\
Caprimulgus affinis & Not identified \\
Centropus bengalensis & Not identified \\
Charadrius sp. & Not identified \\
Chrysocolaptes validus & Not identified \\
Collocalia esculenta & The nest (saliva) is precious \\
Corvus enca & Predators of fish and shrimp \\
Dryocopus javanis & Not identified \\
Egretta garzetta & Not identified \\
Elanus caeruleus & Not identified \\
Geopelia striata & The meat is consumed \\
Halcyon smyrnensis & Insect predators \\
Haliastur indus & Predators of fish and shrimp \\
Hirundo rustica & Not identified \\
Hirundo tahitica & Not identified \\
Lonchura malacca & Not identified \\
Orthotomus atrogularis & Pet bird \\
Orthotomus ruficeps & Pet bird \\
Pandion haliaetus & Predators of fish and shrimp \\
Passer montanus & Not identified \\
Phalacrocorax carbo & Predators of fish and shrimp \\
Picnonotus aurigaster & Pet bird, pollinate flowers \\
Picnonotus goiavier & The meat is consumed, pollinate flowers \\
Picnonotus plumosus & The meat is consumed \\
Picnonotus simplex & Pet bird, pollinate flowers \\
Prinia flaviventris & Pet bird \\
Spilopelia chinensis & The meat is consumed \\
Todiramphus chloris & Insect predators \\
Treron vernans & Not identified \\
Zosterops palpebrosus & Pet bird \\
\hline &
\end{tabular}

The earliest birds observed in the morning were the Ardeidae family. At 06.00 WIB, they were found around the pond and in groups, followed by the presence of other bird species. In addition, one species of nocturnal bird was found during the day, namely Savanna Nightjar (C. affinis). This species is thought to rest during the day, and the birds are usually scattered around the city. The male chirping at night can reach $90 \mathrm{~dB}$ or more in order to disturb the sleep of residents (Cheng et al. 2019).

Several bird species in ATPF play particular roles in the ecosystem and as environmental indicators (Table 3). The birds were found to benefit the community as they can be used for consumption, kept as a pet, used as predatory pests, and assist pollination and dispersal of seeds and fruits. Nevertheless, the birds are also harmful to the community since they may prey on fish and shrimps in ponds.

Oriental Darter is one of the species found at the study site. It is a bird with NT status whose nest presence has decreased drastically (Narayanan et al. 2012). Oriental Darter's presence in ponds causes this species to be considered a nuisance because they prey on and eat fish and shrimps found in ponds. In addition, Oriental Darter is hunted by local residents for meat consumption. This is thought to have an impact on the decline in the population of this bird species. According to Collins (2015), this species, whose habitats are in waters and coasts such as lakes, swamps, and mangroves, often swim with only their head and neck being visible. Oriental Darter is generally piscivorous and, at certain times, eats several large organisms (Narayanan et al. 2016).

In conclusion, this research has succeeded in identifying 38 bird species that consist of 13 orders with 22 families. The order Passeriformes has the highest number of species, namely 15 species, while the family with the most species is Ardeidae, which has five species. There are nine species of migratory birds. Some of the birds found are used by the community for consumption and kept as a pet. Furthermore, these birds act as predators of pests, help pollinate, disperse seeds and fruits, and act as predators of 
fish and shrimps in ponds and indicators of changes in the coastal environment.

\section{ACKNOWLEDGEMENTS}

This study was funded by the Directorate of Research and Community Service, Ministry of Research and Technology, and National Research and Innovation Agency, the Republic of Indonesia through the Post-Doctoral Research Scheme 2021 (No. 12/E1/KP.PTNB/2021)

\section{REFERENCES}

Alves RRN, Leite RCL, Souto WMS. 2013. Ethno-ornithology and conservation of wild birds in Semi-Arid Caatinga of Northeastern Brazil. J Ethnobiol Ethnomed 9 (14): 1-12. DOI: 10.1186/1746-42699-14.

Aryanti NA, Prabowo A, Ma'arif S. 2018. Diversity of bird species in some land use around the area of Mount Argopuro, Probolinggo. Biotropika 6 (1): 16-20. DOI: 10.21776/ub.biotropika.2018.006.01.3. [Indonesia]

Asri NSM, Hambali K, Amir A, Norazlimi NA. 2020. Bird diversity in mangrove areas in Tumpat, Kelantan. Malay Nat J 72 (1): 63-75.

BirdLife International. 2021. IUCN Red List for birds. http://datazone.birdlife.org.

Calimpong, Donna MT, Nuneza OM. 2015. Avifaunal diversity of Bega Watershed, Prosperidad, Agusan del Sur, Philippines. J Biodivers Environ Sci 6 (4): 385-400.

Cheng BY, Shyu GS, Wu SC, Lin HH, Hsu CH, LePage BA, Fang WT. 2019. Fragmented riverine habitats in Taiwan have spatio-temporal consequences, re-distributing Caprimulgus affinis into urban areas leading to a human-wildlife conflict. Sustain 11 (1778): 1-12. DOI: $10.3390 /$ su 11061778 .

Collins W. 2015. Bird of India Pakistan, Nepal, Bhutan, Bangladesh and Sri Langka. Harper Collins Publishers, London.

Dinanti RV, Winarni NL, Supriatna J. 2018. Vertical stratification of bird community in Cikepuh Wildlife Reserve, West Java, Indonesia. Biodiversitas 19 (1): 134-139. DOI: 10.13057/biodiv/d190120.

Eddy S, Basyuni M. 2020. Short Communication: The phenomenon of nipah (Nypa fruticans) invasion in the Air Telang Protected Forest, Banyuasin District, South Sumatra, Indonesia. Biodiversitas 21 (11): 5114-5118. DOI: 10.13057/biodiv/d211116.

Eddy S, Iskandar I, Ridho MR, Mulyana A. 2017. Land cover changes in the Air Telang Protected Forest, South Sumatra, Indonesia (19892013). Biodiversitas 18 (4): 1538-1545. DOI: 10.13057/biodiv/d180432.

Eddy S, Milantara N, Sasmito SD, Kajita T, Basyuni M. 2021a Anthropogenic drivers of mangrove loss and associated carbon emissions in South Sumatra, Indonesia. Forests 12 (187): 1-14. DOI: DOI: 10.3390/f12020187.

Eddy S, Milantara N, Basyuni M. 2021b. Carbon emissions as impact of mangrove degradation: A case study on the Air Telang Protected Forest, South Sumatra, Indonesia (2000-2020). Biodiversitas 22 (4): 2142-2149. DOI: 10.13057/biodiv/d220464.

Eddy S, Ridho MR, Iskandar I, Mulyana A. 2019. Species composition and structure ofdegraded mangrove vegetationin the Air Telang Protected Forest, South Sumatra, Indonesia. Biodiversitas 20 (8): 2119-2127. DOI: 10.13057/biodiv/d200804.

Firdausy MS, Mardiastuti A, Mulyani YA. 2021. The community of Ardeidae Family and distribution of nest trees in Pulau Rambut Wildlife Sanctuary, Jakarta Bay, Indonesia. Adv Biol Sci Res 11: 242-245. DOI: 10.2991/absr.k.210408.040.
Gaston KJ, Cox DTC, Canavelli SB, García D, Hughes B, Maas B, Martínez D, Ogada D, Inger R. 2018. Population abundance and ecosystem service provision: The case of birds. BioSci 68 (4): 264272. DOI: 10.1093/biosci/biy005.

Hakim L, Abdoellah OS, Parikesit, Withaningsih S. 2020. Impact of agricultural crop type and hunting on bird communitiesof two villages in Bandung, West Java, Indonesia. Biodiversitas 21 (1): 57-66. DOI: 10.13057/biodiv/d210109.

Iswandaru D, Febryano IG, Santoso T, Kaskoyo H, Winarno GD, Hilmanto R, Safe'I R, Darmawan A, Zulfiani D. 2020. Bird community structure of small islands: A case study on the Pahawang Island, Lampung Province, Indonesia. Silva Balcanic 22 (1): 5-18. DOI: 10.3897/silvabalcanica.21.e56108.

Jumilawaty E, Mardiastuti A, Prasetyo LB, Mulyani YA. 2011. Waterbirds diversity in Bagan Percut, Deli Serdang North Sumatera. Media Konservasi 16 (3): 108-113. [Indonesia]

Khan MS. 2017. Effect of forest composition on bird species abundance in tropical dry deciduous forest: A case of Bhimbandh Wildlife Sanctuary, India. Biodiversitas 18 (1): 78-85. DOI: 10.13057/biodiv/d180112.

Kolzsch A, Blasius B. 2008. Theoretical approaches to bird migration. J Spec Top 157: 191-208. DOI: 10.1140/epjst/e2008-00641-y.

Labiran J, Iwajomo S. 2018. Factors Influencing Bird Species Richness and Abundance in Surulere Local Government Area of Lagos State, Nigeria. Proceedings of 6th NSCB Biodiversity Conference, Uniuyo 2018. University of Uyo, Uyo, 6-12 May 2018.

MacKinnon J, Philips K, Balen BV. 2010. Burung-burung di Sumatera, Jawa, Bali dan Kalimantan. Perhimpunan Pelestarian Burung Liar di Indonesia, Bogor. [Indonesia]

Maurice ME, Fuashi NA, Mbua RL, Mendzen NS, Okon OA, Ayamba NS. 2020. The environmental influence on the social activity of birds in Buea University Campus, Southwest Region, Cameroon. Interdiscip J Environ Sci Educ 16 (2): e02210. DOI: $10.29333 /$ ijese/6446.

Mosbech A, Johansen KL, Davidson TA, Appelt M, Grønnow B, Cuyler C, Lyngs P, Flora J. 2018. On the crucial importance of a small bird: The ecosystem servicesof the little auk (Alle alle) population in Northwest Greenlandin a long-term perspective. Ambio 47: S226S243. DOI: 10.1007/s13280-018-1035-x.

Nagelkerken I, Blaber SJM, Bouillon S, Green P, Haywood M, Kirton LG, Meynecke J-O, Pawlik J, Penrose HM, Sasekumar A, Somerfield PJ. 2008. The habitat of mangrove for terrestrial and marine fauna: A review. Aquat Bot 89: 155-185. DOI: 10.1016/j.aquabot.2007.12.007.

Narayanan SP, Sreekumar B, Vijayan L, Thomas AP. 2012. Status of the nests of Near-Threatened Oriental Darter Anhinga melanogaster at Kumarakom Heronry. Natl Acad Sci Lett 35 (2): 99-101. DOI 10.1007/s40009-012-0027-9.

Narayanan SP, Thomas AP. 2016. Feeding rate and diet of the Near Threatened Oriental Darter Anhinga melanogaster in Kuttanad Wetlands of Kerala, India. J Glob Biosci 5 (1): 3450-3460.

Priyono B, Abdullah M, Febriyanto MN, Bodijantoro FPMH, Purwantoyo E. 2021. Fig visitor's behaviour in Ungaran mountain, Indonesia. J Phys Conf Ser 1918: 052044. DOI: 10.1088/17426596/1918/5/052044.

Puspitaningtyas DM. 2018. Orchid exploration in Mount Bintan Besar Protected Forest, Bintan Island, Riau Islands Province, Sumatra,

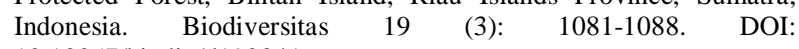
10.13057/biodiv/d190341.

Xu Y, Si Y, Wang Y, Zhang Y, Prins HHT, Cao L, deBour WF. 2019. Loss of functional connectivity in migration networks induces population decline in migratory birds. Ecol Appl 29 (7): 1-10. DOI: 10.1002/eap.1960.

Yustian I, Zulifli H, Setiawan A, Setiawan D, Iqbal M, Apriliani I, Indriati W, Saputra RF, Sumantri H, Pratama R, Prastyo CY, Neberio D, Pragustiandi G. 2017. Panduan Survei Cepat Keanekaragaman Fauna di Sumatera Selatan. FMIPA Universitas Sriwijaya, Palembang. [Indonesian] 